\title{
Seroconversion attributable to vaccination of heifers with the strain B-19 of Brucella abortus
}

\section{Soroconversão atribuível à vacinação de bezerras com a cepa B-19 de Brucella abortus}

\author{
Alessandro José Ferreira dos Santos ${ }^{1 *}$; Katyane de Sousa Almeida ${ }^{2}$; \\ Francisco Baptista ${ }^{3}$; Marco Augusto Giannoccaro da Silva ${ }^{3}$; \\ Bruna Alexandrino ${ }^{2}$; Jardel Martins Ferreira ${ }^{4}$
}

\begin{abstract}
Bovine brucellosis is transmitted by Brucella abortus and causes considerable economic losses to agribusiness. To determine the seroconversion rate attributable to vaccination of heifers with $B$. abortus strain B-19, 330 blood serum samples from 110 heifers aged three to eight months from five properties in the municipality of Araguaína, Tocantins, Brazil, were analyzed. On day zero (D-0), blood samples were collected, and 55 heifers from the intervention group were vaccinated. The remaining blood samples were collected on days seven (D-7), 14 (D-14), and 21 (D-21). The serum samples were analyzed using the buffered acidified plate antigen (BAPA) test. The rate of seroconversion attributable to vaccination was calculated by subtracting from the seroconversion incidence rate in the intervention group the incidence rate of the control group. On D-0, 100\% (110/110) of the heifers were negative in the BAPA test $(95 \%$ CI $[96.70-100 \%], p<0.05)$. On D-7, the seroconversion rate was $94.55 \%(52 / 55)$ $(95 \% \mathrm{CI}[84.88-98.84 \%], \mathrm{p}<0.05)$ in the intervention group and $0 \%(0 / 55)(95 \% \mathrm{CI}[0.00-6.49 \%]$, $\mathrm{p}<0.05)$ in the control group. On D-14, the rate was $98.18 \%(54 / 55)(95 \%$ CI [90.28 - 99.95\%], p < 0.05 ) in the intervention group and $0 \%$ in the control group. Therefore, seroconversion attributable to vaccination varied from $78.39 \%(84.88-6.49 \%)$ to $92.35 \%$ (98.86 - 6.49\%) on D-7 and from $83.79 \%$ (90.28 - 6.49\%) to $93.46 \%$ (99.95 - 6.49\%) on D-14, respectively. On D-21, the seroconversion rate in the 55 heifers from the control group vaccinated on D-14 was $100 \%(55 / 55)(95 \%$ CI [ $93.51-100 \%]$, $p<0.05)$ but was not significantly different $(p>0.05)$ from that of heifers from the intervention group vaccinated on D-7. The results of this study allow making recommendations to the Official Veterinary Service on establishing a vaccination audit, with random collection of blood samples starting on day seven after vaccination in heifers considered vaccinated with $B$. abortus strain B-19 using the BAPA test as a diagnostic test and considering a minimum seroconversion rate of $75 \%$ to evaluate vaccination against brucellosis.
\end{abstract}

Key words: Brucellosis. Diagnosis. Monitoring. PNCEBT. Vaccination.

\footnotetext{
1 Pesquisador, M.e, Agência de Defesa Agropecuária do Estado do Tocantins, Adapec/TO, Araguaína, TO, Brasil. E-mail: dr.alessandro.vet@gmail.com

2 Prof $^{\text {as }} \operatorname{Dr}^{\mathrm{as}}$, Universidade Federal do Tocantins, UFT, Araguaína, TO, Brasil.E-mail: katyanesalmeida@uft.edu.br; bralexandrino@, mail.uft.edu.br

3 Profs. Drs., UFT, Araguaína, TO, Brasil. E-mail: baptista@uft.edu.br; marcogiannoccaro@uft.edu.br

4 Discente de Mestrado, Agência de Defesa Agropecuária do Estado do Tocantins, Adapec/TO, Araguaína, TO, Brasil. E-mail: jardelmf@gmail.com

* Author for correspondence
} 


\section{Resumo}

A brucelose bovina é causada por Brucella abortus gerando perdas econômicas para a cadeia do agronegócio. Objetivando determinar o coeficiente de soroconversão atribuível à vacinação de bezerras com a cepa B-19 de B. abortus, foram analisadas 330 amostras de soro sanguíneo de 110 bezerras com três a oito meses de idade, provenientes de cinco propriedades do município de Araguaína/TO. O dia zero (D-0) foi marcado pela coleta de sangue dos animais do experimento seguida da vacinação das 55 bezerras do grupo intervenção. As outras coletas de sangue foram realizadas nos dias 7 (D-7), 14 (D-14) e 21 (D-21). As amostras de soro foram submetidas ao teste do antígeno acidificado tamponado (AAT). O coeficiente de soroconversão atribuível à vacinação foi calculado subtraindo-se da incidência de soroconversão no grupo intervenção àquela do grupo controle. No D- $0,100 \%(110 / 110)$ das bezerras amostradas não apresentaram reação ao teste do AAT (IC 95\% [96,70\% a 100\%]; p < 0,05). No D-7 a soroconversão no grupo intervenção foi de 94,55\% (52/55) (IC 95\% [84,88\% a 98,84\%]; p < 0,05) e no grupo controle foi nula (0/55) (IC 95\% [0,00\% a 6,49\%]; p < 0,05). No D-14 a soroconversão no grupo controle continuou sendo nula e a do grupo intervenção foi de 98,18\% (54/55) (IC 95\% [90,28\% a 99,95\%]; $\mathrm{p}<0,05)$. Assim, a soroconversão atribuível à vacinação pode variar entre $78,39 \%$ $(84,88 \%$ - 6,49\%) e $92,35 \%$ (98,86\% - 6,49\%), e entre $83,79 \%(90,28 \%$ - 6,49\%) e $93,46 \%(99,95 \%$ $6,49 \%)$ no D-7 e D-14, respectivamente. No D-21 a soroconversão nas 55 bezerras do grupo controle vacinadas no D-14 foi de 100\% (55/55) (IC 95\% [93,51\% a 100\%]; p < 0,05), mas sem diferença significativa $(\mathrm{p}>0,05)$ comparada à resposta no D-7 do grupo intervenção. Os resultados deste estudo permitem recomendar ao Serviço Veterinário Oficial (SVO) que institua auditoria da vacinação, com coleta aleatória de amostras de sangue a partir do sétimo dia em bezerras declaradas como vacinadas com a cepa B-19 de B. abortus, utilizando a prova do AAT como teste de diagnóstico e considerando soroconversão mínima de $75 \%$, visando monitorar a vacinação contra brucelose.

Palavras-chave: Brucelose. Diagnóstico. Monitoramento. PNCEBT. Vacinação.

\section{Introduction}

Brucellosis is an infectious-contagious disease caused by bacteria of the genus Brucella sp. and is endemic in many countries. Brucellosis causes considerable economic loss to dairy and beef production and adversely affects animal and human health because of its zoonotic nature (ALVES; VILLAR, 2011; BRASIL, 2006).

In 2001, the Ministry of Agriculture, Livestock, and Supply (Ministério da Agricultura, Pecuária e Abastecimento-MAPA) acknowledged the need to control brucellosis and developed and launched the National Program for the Control and Eradication of Animal Brucellosis and Tuberculosis (PNCEBT) (FERREIRA NETO et al., 2016). The strategy of the PNCEBT is based on classifying the states of Brazil by the degree of risk for brucellosis and tuberculosis and defining animal disease control strategies to be adopted according to this classification (BRASIL, 2017).

The PNCEBT's specific objectives are reducing the prevalence and incidence of brucellosis and tuberculosis to achieve disease eradication. The strategy for brucellosis control is based on classifying the Brazilian states by the degree of risk for this disease based on the prevalence estimated by studies standardized by MAPA (Figure 1), and defining animal disease control measures to be adopted according to this classification, taking into account the implementation of the measures proposed in the action plan defined by the Official Veterinary Service (OVS) and approved by the Animal Health Department of MAPA (Table 1 and 2) (BRASIL, 2017). 
Figure 1. Prevalence of bovine brucellosis estimated by studies standardized by MAPA in different states of Brazil.

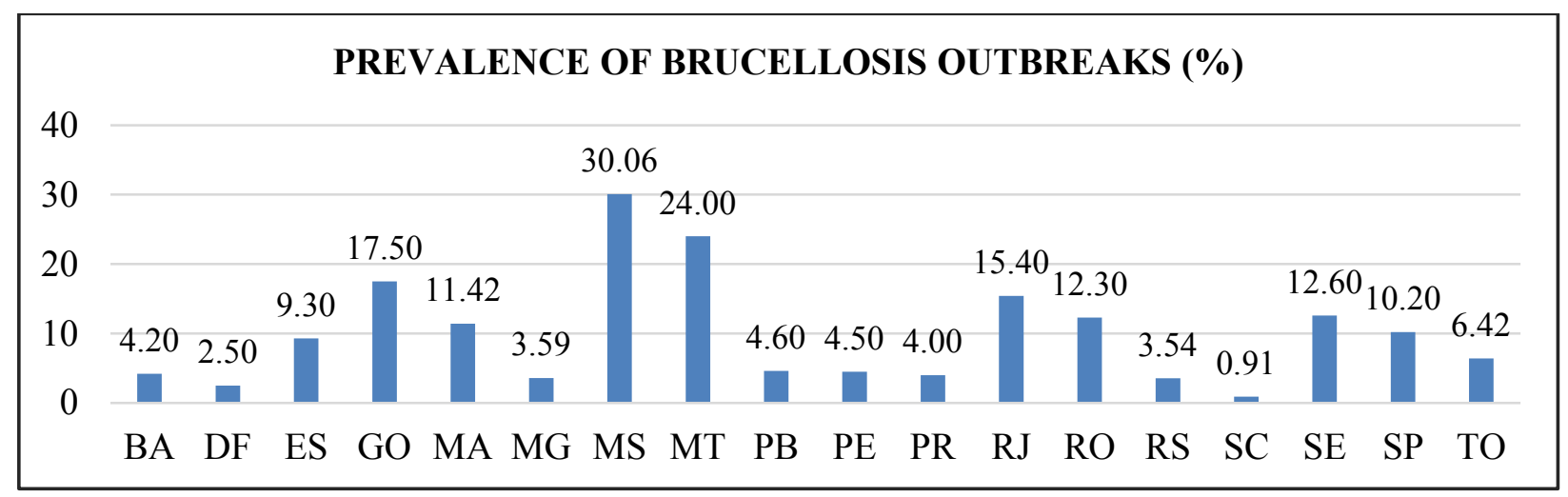

Source: http://www.agricultura.gov.br/assuntos/sanidade-animal-e-vegetal/saude-animal/programas-de-saude-animal/brucelosee-tuberculose/tb-3-estudos-prevalencia.pdf. Accessed on March 5, 2018.

Table 1. Risk classification for brucellosis in cattle and buffalo.

\begin{tabular}{cccccc}
\hline & & \multicolumn{4}{c}{ LEVEL } \\
\cline { 3 - 5 } $\begin{array}{c}\text { PREVALENCE OF } \\
\text { OUTBREAKS (\%) }\end{array}$ & CLASS & INITIAL & \multicolumn{3}{c}{$\begin{array}{c}\text { QUALITY OF EXECUTION OF DISEASE } \\
\text { CONTROL ACTIONS }\end{array}$} \\
\cline { 3 - 6 } & & & LOW & MEDIUM & HIGH \\
\hline$<2$ & $\mathrm{~A}$ & 0 & 1 & 2 & 3 \\
\hline$\geq 2$ and $<5$ & $\mathrm{~B}$ & 0 & 1 & 2 & 3 \\
\hline$\geq 5$ and $<10$ & $\mathrm{C}$ & 0 & 1 & 2 & 3 \\
\hline$\geq 10$ & $\mathrm{D}$ & 0 & 1 & 0 & 0 \\
\hline Unknown & $\mathrm{E}$ & 0 & 0 & & 3 \\
\hline
\end{tabular}

Source: Brasil (2017).

Table 2. Measures to control and eradicate brucellosis according to the risk classification in each state of Brazil.

\begin{tabular}{cl}
\hline CLASS & \multicolumn{1}{c}{ ACTIONS } \\
\hline A & Mandatory control of outbreaks and epidemiological surveillance of outbreaks. \\
\hline B & $\begin{array}{l}\text { Vaccination against brucellosis with vaccine coverage higher than } 80 \%, \text { mandatory control of disease } \\
\text { outbreaks, and epidemiological surveillance of outbreaks. }\end{array}$ \\
\hline C & Vaccination against brucellosis with vaccination coverage higher than $80 \%$. \\
\hline D & Vaccination against brucellosis with vaccination coverage higher than $80 \%$. \\
\hline E & $\begin{array}{l}\text { Vaccination against brucellosis with vaccination coverage higher than } 80 \% \text { and epidemiological anal- } \\
\text { ysis of brucellosis. }\end{array}$ \\
\hline
\end{tabular}

Source: Brasil (2017).

According to the Food and Agriculture Organization of the United Nations (FAO, 2003), B. abortus strain B-19 should be adopted as the standard vaccine for brucellosis control programs in the mass vaccination phase of heifers. FAO (2003) further recommends performing diagnostic tests using the buffered acidified plate antigen (BAPA) test within two to three weeks after vaccination in random samples of heifers vaccinated with strain B-19, and more than $80 \%$ of these animals should 
present antibodies against $B$. abortus. The objective of this approach is to monitor vaccine coverage and the effectiveness of strategies adopted for the control and eradication of this disease.

The reliability of the measures proposed by the PNCEBT is directly related to the surveillance actions performed by the OVS to confirm the quality and effectiveness of disease control measures, focusing on their critical points. Considering that heifer vaccination against brucellosis is a critical step in brucellosis control programs, this study is justified by the need to provide information to the OVS about the identified critical points, which may serve as a parameter for implementing actions that allow better control of vaccination.

Therefore, the objectives of this study were to determine, at the $95 \%$ confidence level, the rate of seroconversion attributable to vaccination of heifers (aged three to eight months) with B. abortus strain B-19 in seven and 14 days after vaccination, and propose a minimum rate of seroconversion as an audit parameter of vaccination. The aim of this strategy is to monitor vaccination against brucellosis in the control phase, in which vaccination assumes a vital role.

\section{Material and Methods}

A total of 330 blood serum samples were collected from 110 heifers (aged three to eight months) originating from five farms located in Araguaína, Tocantins (Brazil), after performing a randomized trial in two groups of heifers selected at random (intervention and control, each with 55 animals).

On day zero (D-0), blood samples were collected, and heifers from the intervention group were vaccinated with a single dose $(2 \mathrm{~mL})$ of a vaccine containing B. abortus strain B-19, and heifers from the control group received a placebo $(2 \mathrm{~mL}$ of $0.9 \%$ sodium chloride). Vaccine and placebo were administered subcutaneously in the neck region. After vaccination, blood samples were collected on days seven (D-7), 14 (D-14), and 21 (D-21).

The randomized clinical trial was carried out until D-14 when the heifers from the control group were vaccinated with $B$. abortus B-19 strain to comply with the requirements of the current legislation. The collection of 55 blood samples from the control group on D-21 allowed measuring the rate of seroconversion on day seven after vaccination in a manner similar to that of the intervention group.

Heifers vaccinated in the second semester of 2016 were branded on the left side of the head with a "V" accompanied by the final number of the year of vaccination (e.g., "V6") whereas heifers vaccinated in the first semester of 2017 were branded with the last figure of the year of vaccination (e.g., "7") to comply with the legislation in force in each period (BRASIL, 2009, 2017).

Blood was obtained by puncture of the jugular vein using $10 \mathrm{~mL}$ vacuum collection tubes, disposable needles $(25 \times 0.8 \mathrm{~mm})$, and connectors suitable for the type of tube used. The collected samples were sent to the Laboratory of Hygiene and Public Health of the Federal University of Tocantins and centrifuged at $3,500 \mathrm{rpm}$ for 10 minutes to collect serum. The serum samples were transferred to microtubes (Eppendorf) and stored at $-20{ }^{\circ} \mathrm{C}$ until analysis (BRASIL, 2006).

An identification tag with a sequential number was attached to the left ear of heifers with an applicator to match each animal with the corresponding serum sample.

All serum samples were analyzed using the BAPA test (Instituto Biológico de São Paulo) (Lot \#001/2017; expiration date, February 2018). The assays were performed at the Hygiene and Public Health Laboratory of the Federal University of Tocantins. The assays were performed as recommended by the Legislation for National Animal Health Programs of Brazil (BRASIL, 2009). 
Sera samples and antigen containing Rose Bengal-stained $B$. abortus were thawed and kept at $22 \pm 4{ }^{\circ} \mathrm{C}$ for at least 30 minutes. Afterwards, the serum was homogenized, and $30 \mu \mathrm{L}$ of each sample was deposited on a glass plate, using a micropipette. The same procedure was carried out for the antigen, which was deposited next to the serum sample, without mixing with it. Ten samples were processed per assay. Positive and negative control sera were used in each assay.

The serum and antigen were mixed by means of a simple mixer with circular movements, so as to obtain a circle of about two centimeters. The plate was then shaken with an oscillating movement for four minutes. Afterwards, reading was accomplished by placing the plate in a reading box with indirect light. Samples that showed agglutination were considered reagent. The results were noted, and the agglutination reactions occurred after four minutes were disregarded.
Statistical analyses were performed using the software WinPepi ${ }^{\mathrm{TM}}$ version 11.43 and R Studio ${ }^{\mathrm{TM}}$ version 1.1.447, and the rate of seroconversion attributable to vaccination of heifers with $B$. abortus strain B-19 was determined using the following formula:

\section{Seroconversion rate $=I_{i}-I_{c}$}

Where $\boldsymbol{I}_{\boldsymbol{i}}$ and $\boldsymbol{I}_{\boldsymbol{c}}$ are the seroconversion rates in the intervention and control groups, respectively.

\section{Results and Discussion}

On D-0, 100\% (110/110) of the heifers were negative in the BAPA test (95\% CI [96.70 - 100\%], $\mathrm{p}<0.05)$. On D-7, the seroconversion rate was 94.55\% (52/55) (95\% CI [84.88 - 98.84\%], p < $0.05)$ in the intervention group and $0 \%(0 / 55)(95 \%$ CI [0.00 - 6.49\%], $\mathrm{p}<0.05)$ in the control group. On $\mathrm{D}-14$, the rate was $98.18 \%(54 / 55)(95 \%$ CI $[90.28$ $-99.95 \%$ ], $\mathrm{p}<0.05)$ in the intervention group and $0 \%$ in the control group (Table 3).

Table 3. Seroconversion rate in heifers from the intervention and control group.

\begin{tabular}{lcccc}
\hline \multirow{2}{*}{ DAY } & \multicolumn{2}{c}{ INTERVENTION GROUP } & \multicolumn{2}{c}{ CONTROL GROUP } \\
\cline { 2 - 5 } & SEROCONVERSION & $95 \% \mathrm{CI}$ & SEROCONVERSION & $95 \%$ CI \\
\hline D0* & $0 \%$ & $0-6.49 \%$ & $0 \%$ & $0-6.49 \%$ \\
D7 & $94.55 \%^{\mathrm{a}}$ & $84.88-98.84 \%$ & $0 \%$ & $0-6.49 \%$ \\
D14** & $98.18 \%$ & $90.28-99.95 \%$ & $0 \%$ & $0-6.49 \%$ \\
D21 & - & - & $100 \%^{\mathrm{a}}$ & $93.51-100 \%$ \\
\hline
\end{tabular}

$(*)$ Vaccination with B. abortus strain B-19 in heifers from the intervention group.

$(* *)$ Vaccination with B. abortus strain B-19 in heifers from the control group.

Note ${ }^{1}$ The same letters in the columns indicate the absence of significant differences in seroconversion $(\mathrm{p}>0.05)$ between the intervention and control groups seven days after vaccination.

Note $^{2}$ The seroconversion rate was calculated using the lower and upper limits of the confidence interval for the intervention group and the upper limit of the confidence interval for the control group.

Therefore, the rate of seroconversion attributable to vaccination varied from $78.39 \%(84.88-6.49 \%)$ to $92.35 \%$ (98.86- $6.49 \%$ ) on D-7 and from $83.79 \%$ (90.28 - 6.49\%) to $93.46 \%(99.95-6.49 \%)$ on D-14, respectively. On D-21, the seroconversion rate in the 55 heifers from the control group vaccinated on
D-14 was 100\% (55/55) (95\% CI [93.51 - 100\%], $\mathrm{p}<0.05)$ but was not significantly different $(\mathrm{p}>$ 0.05 ) from that of heifers from the intervention group vaccinated on D-7 (Table 3).

Ferreira Neto et al. (2016) have shown that a successful animal disease control program should 
be updated as the epidemiological status evolves and new technologies emerge. Nonetheless, failures in combating the disease can occur because of program fragility or dubiousness, or even non-compliance of rules, among which Paulin and Ferreira Neto (2003) mention the poor use of vaccines and fraud of reports.

Baptista et al. (2012) determined the prevalence and risk factors for brucellosis in the state of Tocantins and found that vaccination against brucellosis in the Araguaína microregion has not been a protective factor against the disease. This is because, according to the vaccination status of heifers (aged $>24$ months) reported by the owners or farm managers, the rate of seropositivity for brucellosis was similar in cows with and without vaccination history $(\mathrm{p}>0.05)$, and this result was attributed to the lack of criterion in executing and monitoring vaccination.

The PNCEBT were updated using the Normative Instruction No. 10, from March 3, 2017, which maintained the B. abortus strain B-19 as the official vaccine in the program for vaccination of heifers with three to eight months of age. Yet, this strain may be replaced with a non-antibody-inducing vaccine, strain RB-51, for vaccination of bovines. However, the use of the RB-51 strain for vaccinating heifers aged three to eight months would prevent monitoring vaccination coverage because the BAPA diagnostic test does not detect the antibodies produced by the animals after immunization.
In Brazil, with the exception of the state of Santa Catarina, which has a very low or negligible risk classification for brucellosis, the other states have a classification that ranges from low risk to high risk according to the standardized studies of brucellosis prevalence, in addition to those in which the risk is still unknown. In these states, mass vaccination of heifers (aged three to eight months) with a vaccine coverage higher than $80 \%$ is the primary strategy for brucellosis control adopted by PNCEBT. In this phase of the program, FAO (2003) recommends using B. abortus B-19 strain, which allows monitoring the effectiveness of the adopted zoonosis control strategies using BAPA tests.

The results of the chi-square test $\left(\chi^{2}\right)$ for interdependence indicated that the positivity of the BAPA test in heifers of three to eight months of age depended on the vaccination with the B. abortus B-19 strain (Table 4). Paulin and Ferreira Neto (2003) stressed the need to develop a surveillance system for brucellosis that should be implemented and managed by the OVS using audit-based methods for quality control of vaccination. Therefore, the seroconversion rates obtained in this study allow us to say $(\mathrm{p}<0.05)$ whether a given batch of heifers was vaccinated with the $B$. abortus B-19 strain from the seventh day after the supposed vaccination, thus allowing the adoption of corrective measures aimed at improving brucellosis control programs in cattle.

Table 4. Results of the buffered acidified plate antigen test seven days after vaccination of heifers from the intervention group.

\begin{tabular}{cccc}
\hline GROUP & SEROCONVERSION & NEGATIVE & TOTAL \\
\hline Intervention & 52 & 3 & $\mathbf{5 5}$ \\
Control & 0 & 55 & $\mathbf{5 5}$ \\
\hline TOTAL & $\mathbf{5 2}$ & $\mathbf{5 8}$ & $\mathbf{1 1 0}$ \\
\hline
\end{tabular}

chi-square test $\left(\chi^{2}\right)=94.8641$, degree of freedom $=1$, p-value $<2.2 \mathrm{e}^{-16}$. 


\section{Conclusion}

The results of this study allow us to recommend to the OVS the establishment of vaccination audits with a random collection of blood samples from day seven after heifers were declared as vaccinated with $B$. abortus strain B-19, using the BAPA test as a diagnostic tool, and considering a minimum seroconversion rate of $75 \%$. The objective of this strategy is to monitor the vaccination programs developed by veterinarians enrolled in the National Program for the Control and Eradication of Animal Brucellosis and Tuberculosis (PNCEBT).

\section{Acknowledgments}

We are grateful to the farmers who provided the heifers for this experimental trial and to the veterinarian Dr. José Wilson Dias Brito, owner of the Laboratory for Zoo-sanitary Diagnosis Guilherme Dourado.

\section{Animal Research Ethics Committee}

This study was approved by the Animal Research Ethics Committee of the Federal University of Tocantins under Process No 23101.005895/2016-10 and complied with biosafety and ethical standards.

\section{References}

ALVES, A. J. S.; VILLAR, K. S. Brucelose bovina e sua situação sanitária no Brasil. Revista de Educação Continuada em Medicina Veterinária e Zootecnia do CRMV/SP, São Paulo, v. 9, n. 2, p. 12-17, 2011.

BAPTISTA, F.; LEITE, R. C.; HADDAD, J. P. A.; ALMEIDA, K. S.; NARDI, C. P. P. Prevalence and risk factors for brucellosis in Tocantins and brazilian national programs to fight this disease. Revista Patologia Tropical, Goiânia, v. 41, n. 3, p. 285-294, 2012. DOI: 10.5216/rpt.v41i3.20755

BRASIL. Instrução Normativa $\mathrm{n}^{0} 10$, de 03 de março de 2017. Ministério da Agricultura, Pecuária e Abastecimento. Secretaria de Defesa Agropecuária. Poder Executivo. Diário Oficial [da] União, Brasília, 2017. Edição 116, Seção 1, p. 4-8.
BRASIL. Manual de legislação: programas nacionais de saúde animal do Brasil. Ministério da Agricultura, Pecuária e Abastecimento. Brasília: Secretaria de Defesa Agropecuária. Departamento de Saúde Animal, 2009. $440 \mathrm{p}$.

BRASIL. Manual técnico: Programa nacional de controle e erradicação da brucelose e tuberculose. Ministério da Agricultura, Pecuária e Abastecimento. Brasília: Secretaria de Defesa Agropecuária. Departamento de Saúde Animal, 2006. 188 p.

FOOD AND AGRICULTURE ORGANIZATION OF THE UNITED NATIONS - FAO. Guidelines for coordinated human and animal brucellosis surveillance. Rome: Animal Production and Health Division, FAO Agriculture Department, 2003. n. 156, 46 p.

FERREIRA NETO, J. S.; SILVEIRA, G. B.; ROSA, B. M.; GONÇALVES, V. S. P.; GRISI-FILHO, J. H. H.; AMAKU, M.; DIAS, R. A.; FERREIRA, F.; HEINEMANN, M. B.; TELLES, E. O.; LAGE, A. P. Analysis of 15 years of the national program for the control and eradication of animal brucellosis and tuberculosis, Brazil. Semina: Ciências Agrárias, Londrina, v. 37, n. 5, p. 3385-3402, 2016. Supplement 2. DOI: $10.5433 / 1679-0359.2016 v 37 n 5$ Supl2p3385

PAULIN, L. M.; FERREIRA NETO, J. S. O combate à brucelose bovina: situação brasileira. Jaboticabal: Fundação de Estudos e Pesquisas em Agronomia, Medicina Veterinária e Zootecnia, 2003. 154 p. 
